\title{
The Role of Muhammadiyah and Nahdlatul Ulama in the Making of Sharia-based Regional Regulation in the City of Tasikmalaya, Indonesia
}

\author{
Ma'mun Murod Al-Barbasy ${ }^{1}$, Ali Noer Zaman ${ }^{2}$ \\ \{mamun.murod@umj.ac.id ${ }^{1}$, alinoerzaman@umj.ac.id²\} \\ Universitas Muhammadiyah Jakarta, Indonesia ${ }^{1,2}$
}

\begin{abstract}
This paper describes the role of Muhammadiyah and Nahdlatul Ulama in the making of the Perda syariah number 12/2009 in the City of Tasikmalaya. Data is collected by document study and interview with key persons of both organizations. The study reveals that, as the mainstream mass organization, Muhammadiyah and Nahdlatul Ulama tend to reject the implementation of the Sharia Law in local regulation, which was in contrast to those of non-mainstream Islamic mass organizations such Hizbut Tahrir Indonesia (HTI), Front Pembela Islam (FPI), Laskar Thaliban, Majelis Ulama Indonesia (MUI) and PKPPSI (Presidium Komite Perjuangan Penegakan Syatiat Islam/Presidium of the Islamic Sharia Enforcement Struggle Committee). In this case, the research highlights four roles of these organizations such as guardian of religious moderation, providing religious legitimacy, guardian of democracy, and pressure group.
\end{abstract}

Keywords: Sharia Law, Local Regulation, Muhammadiyah, Nahdlatul Ulama.

\section{Introduction}

Towards independence and during the hearing in the Constituent Assembly in the late 1950s, Muhammadiyah, Nahdlatul Ulama (NU), and other Islamic organizations were among those fought consistently for the enactment of Islamic Sharia in Indonesia. Even during the New Order era, Muhammadiyah and NU often took opposite views with the Suharto government regarding state ideology, Pancasila, the Bill of Pancasila's Implementation and Understanding Guidelines (P4), Pancasila as the Only Ideology in Indonesia, Marriage Bill of 1974, and Issue of Local Religions and Beliefs (Aliran Kepercayaan) [1][2].

In the post-New Order era, however, the political attitudes of Muhammadiyah and NU changed dramatically. When Islamic parties and several Islamic organizations tried to bring back the Jakarta Charter into the Preamble and Article 29 of the 1945 Constitution [3][4][5][6],

Muhammadiyah and NU had different response to this effort, as both agreed to maintain the formulation of the Preambule, paragraph four and Article 29 of the 1945 Constitution adopted on August 18, 1945 which removed the Jakarta Charter formulation [3].

Likewise, when the phenomenon of the sharia-based regional regulation (Perda Syariah) [7] emerged, NU and Muhammadiyah took positions which were not in line with non-mainstream Islamic groups. These two big mass organization firmly rejects perda shariah. Muhammadiyah issued a circular number 10/EDR/I.0/I/2002 dated August 16, 2002, stating that it rejects political maneuver to formalize Islamic shari'a and to adopt the Jakarta Charter in the Preamble and Article 29 of the 1945 Constitution. Through Alim Ulama National Conference On 27-28 
July 2006 in Surabaya [8], on the other hand, NU issued a Declaration of Loyalty to the 1945 Constitution and Pancasila [9].

The position of Muhammadiyah and NU is an example of how Islamic organizations have transformed their ideological position towards Pancasila, from critical and skeptical as they demonstrated during their debates in the Committee for Preparatory Work for Independence (BPUPK) and sessions in the Constituent Assembly, into the ones who are accommodative towards Pancasila. Their former standing is however now adopted by non-mainstream Islamic groups that emerged especially after the fall of the New Order in 1998, who were ideologically oriented to Islamic Khilafah and Islamic Sharia enforcement inspired by movement and thought from Islamic scholars in the Middle East [10].

\section{Research Method}

This research puts the making of sharia regulation number 12 of 2009 in the city of Tasikmalaya, West Java as a case study. Data is obtained through literature review, including exploring historical materials related to relations between Islam and the state in the national and regional contexts of Indonesia. To enrich the data, this study also conducted in-depth interviews with leaders of important organizations such as the Chairman of the Moslem Ulama Council (MUI) in Tasikmalaya City, KH. Acep Mubarok, Chairperson of city branch of Muhammadiyah in Tasikmalaya PD Iif Syamsul Arif, former Chairman of Nahdlatul Ulama in Tasikmalaya City, KH. Iman Suparman, and its current chairman, KH. Didi Hudaya. Other key informants include the Secretary of Tasikmalaya City branch of Hibut Tahrir Indonesia, Abdullah Mufti, Chairman of the Tasikmalaya City branch of Islamic Unity (PERSIS) Lukman Hakim, Chairman of Tasikmalaya City branch of Islamic Defender Front (FPI), KH. Nuril Mubin, and the initiator of Presidium of the Islamic Sharia Enforcement Struggle Committee/PKPPSI, KH. Miftah Fauzi. Data is then analyzed in three steps from reduction in order to selecting and sorting out information relevant to research, descriptive presentation of data and, finally, interpretation of the selected data.

\section{Discussion}

The role Muhammadiyah and NU of Tasikmalaya City in relation to the making of local Islamic regulation is much dependent on the persons who occupy leadership. As mass organization, both Muhammadiyah and NU have political policies, including those related to the application of Islamic Sharia. But their role in its implementation in a local context would be influenced by the leadership style.

\subsection{The Guardian of Religious Moderation}

In Indonesia, Muhammadiyah and NU are Sunni representations which tried to find a synthesis of the political thoughts by adopting moderate ideology (tawasuth), tolerance (tasamuh), and balance (tawazun). When addressing every problem, they always try to take the tawasuth way. In the local political context, the character of tawasuth was also demonstrated by Muhammadiyah dan NU in the debate concerning the perda shariah number 12 of 2009, produced in Tasikmalaya City, West Java. Organizationally, Muhammadiyah and NU took 
different positions with non-mainstream Islamic mass organizations, such as Hizbut Tahrir Indonesia (HTI), Front Pembela Islam (FPI), Laskar Thaliban, Majelis Ulama Indonesia (MUI) and PKPPSI (Presidium Komite Perjuangan Penegakan Syatiat Islam/ Presidium of the Islamic Sharia Enforcement Struggle Committee), which supported the regulation, understood as the implementation of Islamic Shariah [11]. In this case, Muhammadiyah and NU take themselves as guardian of religious moderation. This role is carried out to ensure that the regulation has a moderate face.

The role has been demonstrated by Muhammadiyah and NU since the introduction of the draft of the regulation by PKPPSI.

"Muhammadiyah at the time was actually hoping that the local government of Tasikmalaya would produce regulation on daily matters. When we got the draft, the Mayor was asking for input as soon as possible. It was on June or July (2009). The draft was however concerning Social Norms or Perda Tata Nilai, which in fact have no punishment. So, it was like accessories. How a regulation did not have punishment? If someone violates the regional regulation, what kind of punishment will be given?"1

Muhammadiyah admitted that it was in a difficult position when it has to address the efforts to formalize Islamic Sharia. Organizationally, Muhammadiyah firmly does not agree with it. But many of its members were enthusiastic and supporting the implementation of Sharia regulation. Even, the Mayor of Tasikmalaya at the time, Syarif Hidayat, was a Muhammadiyah cadre, and historically, Muhammadiyah had supported efforts to establish an Islamic State in Indonesia, both in the BPUPK (Committee for Preparatory Work for Independence), the Committee Nine, and Constituent Assembly sessions. ${ }^{2}$

NU's position is also not much different from Muhammadiyah. Even though NU explicitly stated from the beginning that it did not want to be involved in the discussion of the implementation of the Islamic regulation, especially if the draft given concerns only with daily matters which is far from the main message of the Islamic Shariah, namely the common good (Maslahati Al-Ammah). It was confirmed by KH. Iman Suparman, Chairman of the NU of Tasikmalaya City.

"From the beginning, NU did not want to be involved in the discussion of the Sharia Regulation, especially after knowing that the contents of the draft) only talk about trivial things that are not fundamental or substantive from Islamic Sharia itself. The basic things of the Islamic Sharia are not included in the draft of the regulation. If I'm not mistaken, it occurred in 2009, and the name of the draft was 'Islamic Sharia', a copy paste from the Aceh Qanun. This is what makes NU not interested in the discussion of the sharia regulation." 3

Muhammadiyah and NU received the draft of the regulation from the Indonesian Ulema Council (MUI). To respond it, Muhammadiyah invited board members and the leaders of their autonomous organizations, both at the province and City levels. In principle, Muhammadiyah

\footnotetext{
${ }^{1}$ Interview with Iif Syamsul Arif, Chairperson of Muhammadiyah City of Tasikmalaya PD on January 1, 2013 at the Muhammadiyah Office of Tasikmalaya City.

${ }^{2}$ Ibid.

${ }^{3}$ Interview with KH. Iman Suparman at the STAINU Office on March 19, 2014.
} 
objects to the name "Perda Syariat" and some other articles, especially those relating to personal matters. NU on the other hand held the bahsul masail or religious discussion. ${ }^{4}$ Like Muhammadiyah, bahsul Masail questions the name of the perda sharia. It then proposed a moderate name which do not use the term of Shariah, a change which was accommodated during discussions at regional people's assembly, at Tasikmalaya City.

The fact that Muhammadiyah and NU did not dominate the making process of regional regulation number 12/2009 was also reflected in the content of the Perda which did not show the fully moderate face. There are several articles which still look extreme (tatharuf) and are far from wasathiyah (moderate) such as naming abortion and heresy as a despicable behavior without any comprehensive description. If Muhammadiyah and NU were actively involved, it would be possible that those articles could be minimized or even completely eliminated.

Although Muhammadiyah and NU did not dominate, at least it has contributed to coloring the contents of the regulation to be more moderate. In this context, Muhammadiyah and NU have played the role as guardians of religious moderation.

\subsection{The Provider of Religious Legitimacy}

In the political context, Muhammadiyah and NU have always been taken into consideration and referenced, at national as well as regional level. In addressing political policies that have a wide impact on society, Muhammadiyah and NU are always involved. In many of perda shariah making regulation, these two Islamic organizations have contributed [12][13]. Only in a few cases were Muhammadiyah and NU absent. ${ }^{5}$

Whatever the role of Muhammadiyah and NU is, those who propose the application of Islamic Sharia, including political parties of any ideologies and agenda, feel that they would have religious legitimacy if these two big organizations are invited. This religious legitimacy is important, if the regulation is related to Islamic Sharia.

The religious legitimacy is also important in producing Perda shariah number 12 of 2009 of Tasikmalaya City. Muhammadiyah and NU participated in the discussion, although their role was not the same as they did in other regions due to different urgency. In Tasikmalaya City they took passive position, as demanded by the political situation at the time, which is risky to be criticized by supporters of the perda shariah, considering them being inconsistent. This perception was observed correctly by Muhammadiyah and NU leaders. Chairman of NU KH. Didi Hudaya, for example, stated:

"If there is such an assumption, yes, it is right, because there is an ambivalence within NU community concerning perda shariah number $12 / 2009$. At the time when I was not yet elected as the regional head of NU, NU firmly rejected the draft. NU, as well as Muhammadiyah, I saw them only giving the suggestion to the Special Committee of sharia regulation. But the suggestion is not binding. The same reaction also came from university. So, the majority of Muslim leaders and academicians in the City of

4 Regrettably, the files related to the implementation of the Bahsul Masail was not successfully obtained. During the interview, KH. Iman Suparman, assisted by several students, tried to search the archives in the NU office, but was not able to find them.

5 Two regions: Garut and the City of Tasikmalaya are examples of the non-dominant role of Muhammadiyah and NU in the making of the Perda. As they were not dominant, efforts to formalize Islamic Sharia in the form of a Regional Regulation have failed. In the City of Tasikmalaya, the nondominant role of Muhammadiyah and NU caused the Perda formulation looks less moderate. 
Tasikmalaya rejected the draft. But due to the powerful and influential local house of representative (DPRD), the draft was finally adopted" ${ }^{6}$ Arif:

Muhammadiyah position, which is not very different from NU, expressed by Iif Syamsul

"Some say, if Muhammadiyah wants to support the bill, it must be total, whatever the risks. If Muhammadiyah supports Islamic Sharia implementation, it is not an anomaly. History said that Muhammadiyah had been involved in a political process supporting the implementation of Islamic Sharia. But if now Muhammadiyah does not support the perda shariah, show it publicly, do not be hypocrite. This was the difficulty faced by Muhammadiyah at that time. We did not make a written statement of support. If Muhammadiyah was invited and be involved in the processes, it was to mean that the content of the Perda shariah would not be extreme. In fact, the initiators of this shariah regulation were Islamic mass organizations and individuals who are known to be radical. "7

The perception that Muhammadiyah and NU tended to reject the perda shariah was also expressed by by Agus Wahyudin, Chairperson of the Sharia Regional Regulation Special Committee. He said in a hearing with the House of representative of Tasikmalaya City, that these two Islamic organizations tended to reject the efforts to implement the perda shariah in Tasikmalaya City.

"During a hearing with the local house of representative (DPRD), NU refused that the Islamic Shari'a would be upheld. It was attended by NU regional supreme council KH. Affan, and regional executive council, KH. Faith. They rejected the perda shariah. NU does not want that local regulations have Shari'a smell, such as those supervising belief and worship. Unless local regulations relate to muamalah (commercial transactions), NU will support them. Things like headscarf of all kinds and praying should not be put under regulation, as they are parts of private domain. Islamic law does not need to intervene in such a domain. "

"Muhammadiyah also had same position as represented by its regional chairman, Pak Iif (Syamsul Arif), and another board member, Budi Ahdiath. Briefly, Muhammadiyah and NU tend to refuse shariah-based regulation, although they did not state it expressively. Al-Washliyah gave his views, but it did not want neither did it reject. It means that Al-Washliyah considered that these things need to be regulated. " 8

The enactment of the perda sharia Tasikmalaya illustrates the weak coordination among opponents of the formalization of Sharia, such as Muhammadiyah, NU, and other elements. This conclusion was expressed by KH. Didi Hudaya:

"Then it seems to be no coordination between Muhammadiyah and NU as the two largest organizations in addressing the perda shariah. Both had their own way to

\footnotetext{
${ }^{6}$ Interview with KH. Didi Hudaya at his residence, February 20, 2014.

${ }^{7}$ Interview with Iif Syamsul Arif at the Tasikmalaya City PD Muhammadiyah Office, Januari 1, 2013.

${ }^{8}$ Interview with Agus Wahyudin at the Tasikmalaya City House of Representative, Nopember 11, 2014.
} 
respond, although they had same position. In both organizations lies many variants from the liberal to conservative, and this variety colored the response to the perda shariah. "9

The indecisive responses of Muhammadiyah and NU regarding the perda shariah number $12 / 2009$ gave impression that the two organizations fully supported perda shariah, which could not be ignored completely. Didi Hudaya said:

"As there was no full rejection of the perda shariah, it was understood that Muhammadiyah dan NU have accepted it. I have never heard a direct or written rejection from Muhammadiyah and NU. There is no such thing. Even when NU local branch (Kota Tasikmalaya) was led by PNS (Civil Servant), it tended to address softly this perda shariah. But after being led by KH. Didi Hudaya, it might have different view."10

The unobvious support of Muhammadiyah and NU should be seen as a form of religious legitimacy that they gave. Without their endorsement, it is believed that regional shariah regulation number 12/2009 would be ratified with main support from non-mainstream Islamic mass organizations. Politically speaking, all political parties in the local house representative also did not object it, be it for political motivation or for their Islamic awareness.

\subsection{The "Guardian" of Democracy}

The third role played by Muhammadiyah dan Nahdlatul Ulama is to oversee and control the making of Sharia-based regulation. In another word, they behave as "guardian" of democracy, with the aim to ensure that the making of the perda shariah number 12 of 2009 is carried out through civilized political processes, in accordance with existing democratically political mechanisms. Acep Deni stated that the making of Perda number 12/2009 is procedural, very democratic and constitutional. There is no coercion during the process. Philosophical, juridical, sociological, religious and political studies have all been conducted.

"All aspects of the regulation have been achieved according to the procedure. Juridical, sociological, and philosophical studies have been conducted. The religious and political aspects were also examined. So, everything has been fulfilled. The process was good, the channel of consultation was given, and the aspiration from the people were open. Many components of society needed this regulation. There were signatures from community members, Muslims, ajengan, pesantren, and other community representatives. Even minority groups, such as Christians, were invited. So, the process was very complete. The problem laid only on the packaging and harmonization of the contents of the draft. This was in some sense disappointing. The draft submission was also very close to the recess period. Due to the 2009 election, the draft should be accepted before the end of the Ramadan 2009."11

\footnotetext{
${ }^{9}$ Interview with KH. Didi Hudaya at his residence, Februari 20, 2014.

${ }^{10} \mathrm{Ibid}$.

${ }^{11}$ Interview with Asep Deni Dumairi at his residence, November 12, 2014.
} 
The same statement was also given by Agus Wahyudin who said that all procedures related to the making of Perda shariah 12/2009 were correct, in line with the existing legal regulations, accommodating all aspirations and all parties.

"This regulation was born through a democratic process. All were involved. Even those who did not support were invited. Muhammadiyah and NU, who tend to reject it, were also present. All were asked for their views. Of course, those who often came here (the local house of representative (DPRD) were demonstrations that supported the regulation, including FPI, LPI, GPI, and the Taliban. Hizb ut-Tahrir was also involved. Muhammadiyah and NU refused the regulation. The Persis' position was not clear. Muhammadiyah considered that putting Islamic Sharia as the regulation would degrading Muhammadiyah. I still remembered what the Muhammadiyah position during hearing session was"12

Echoing what Agus Wahyudin said, Budi Ahdiat stated that all procedures for making a law had been passed. If there are those who accuse that the making process was undemocratic, the assumption is totally wrong. "That there were indeed many unusual articles in the draft (PKPPSI), that's another matter. That is our job to harmonize them. Certainly, the mechanism for making it is in accordance with the procedures for making regional regulations. ${ }^{13}$ " During the drafting of the regulation, the DPRD summoned Islamic mass organizations, even though the time of the invitation was varied. Budi Ahdiat put categorized the invited mass organizations into three categories, such as extreme radicals: FPI, HTI, Mujahiddin and Thaliban; middle way mass organizations which include Muhammadiyah, NU, and Persis, and mass organizations that oppose the draft, such as Ansor and PMII (Indonesian Islamic Student Movement). ${ }^{14}$

The above explanation illustrates that in substance Muhammadiyah and NU have the same way of thinking, which tends not to support the formalization of Islamic sharia. Concerning Perda shariah number 12/2009, both organizations maintained their position, and limited themselves by overseeing the democratic hearing of the draft according to existing rules.

\subsection{Pressure Group}

Political pressure is often referred to as the practice of pressure groups [14]. It was carried out by Muhammadiyah and NU as well non-mainstream Islamic organizations by influencing the making process of local regulations, giving inputs which are in line with their religious views. The political pressure exerted by them is more pronounced, although the level of effectiveness is not necessarily maximum. They also put pressure by taking the street to voice their demands before the office of the Major and the House of Representative. According to KH. Nuril Mubin and Budi Ahdiat, the two opposing groups of the sharia based regional regulation were often involved in physical contacts during their demonstrations.

For Muhammadiyah and NU, the demand for the implementation of sharia regulation in Tasikmalaya City is a serious problem that must be addressed. However, their position was influenced by the political and ideological position they had regarding the sharia law, which rejects its formalization in the implementation. Their way of communication was also shaped

\footnotetext{
${ }^{12}$ Interview with Agus Wahyudin at the Tasikmalaya City House of Representative, August 13, 2015.

${ }^{13}$ Interview with Agus Wahyudin at the Tasikmalaya City House of Representative, August 13, 2015.

${ }^{14}$ Ibid.
} 
by the style and quality of their leaders. Their passive response regarding the perda shariah has attracts serious attention from policy makers in Tasikmalaya City, as they are representatives of mainstream Muslim community in Tasikmalaya.

The awareness of the important position of Muhammadiyah and NU has stimulated the local house of representative to often take a pro-active position to solicit inputs from Muhammadiyah and NU. In this sense, the passivity of Muhammadiyah and NU is actually quite fruitful, as can be seen from the face of Perda No. 12/2009 which was more moderate than the initial draft of the regulation. The controversy of Perda shariah number 12/2009 was much provoked by incomplete explanation regarding some controversial points.

\section{Conclusion}

Muhammadiyah and NU have cleared a position of not to formalize Islamic sharia as demanded by Islamic parties and non-mainstream Islamic mass organizations. However, responding to the effort of enacting sharia-based regulation in many regions in Indonesia, they did not always have the same reaction, as it was influenced by their different roles.

From the case study of sharia-based regional regulation in the City of Tasikmalaya, West Java, Indonesia, we observe some roles of Muhammadiyah and NU. First, as the guardian for religious moderation. The role was played to maintain that the perda shariah would remain moderate (tawasuth) and not rigid or extreme (tatharruf). Second, the provider of religious legitimacy. As mainstream mass organization, the position and political support of Muhammadiyah and NU were very important. Proponents of perda shariah feel that without the support of Muhammadiyah and NU, the Islamic regulations they proposed would be less perfect. Third, the "guardian" of democracy. This role was taken to ensure that the perda sharia did not violate the legal procedures. The process must also be democratic and constitutional, involving many components of the community and decided in a constitutional forum as well, namely in the house of representative of Tasikmalaya City. And fourth, the pressure group. Organizationally, Muhammadiyah and NU did not support the sharia-based regional regulation. They are known as moderate Islamic organizations (tawasuth). Therefore, in the discussion of the draft of the perda shariah, their positions were more passive. This passive position thus made the house of representative of Tasikmalaya City take a pro-active response by asking input from these two large organizations.

\section{References}

[1] A. A. Thaba and A. Gaffar, "Islam dan negara dalam politik Orde Baru (1966-1994)." [Yogyakarta]: Universitas Gadjah Mada, 1994.

[2] M. S. Anwar, Pemikiran dan aksi Islam Indonesia: sebuah kajian politik tentang cendekiawan Muslim Orde Baru. Paramadina, 1995.

[3] M. Abdillah, "Ways of constitution building in Muslim countries," Islam rule law Between sharia Secul., pp. 51-64, 2008.

[4] N. Burhanudin, Penegakan Syariat Islam Menurut Partai Keadilan. Al-Jannah, 2004.

[5] K. Zada, "Perda Syariat. Proyek Syariatisasi yang Sedang Berlangsung," Tashwirul Afkar. J. Refleks. Pemikir. Keagamaan dan Kebud., vol. 20, pp. 8-20, 2006.

[6] A. Hidayat, "Formalization of Sharia Law in Indonesia: A Constitusion Perspective," Discourse, vol. 6, 2002. 
[7] Rakyat Merdeka Online, "Dr. Haedar Nashir: Banyak Perda Syariah Mengandung Unsur-Unsur Diskriminatif," Rakyat Merdeka Online, 2013. [Online]. Available: http://www.rakyatmerdekaonline.com/read/2013/07/17/118916/Dr.-Haedar-Nashir:-BanyakPerda-Syariah-Mengandung-Unsur-unsur-Diskriminatif-.

[8] Tempo, "Edition 24/XXXV/07," Tempo, 2006.

[9] Jawa Pos, "Edition 27 Juli 2006," Jawa Pos, 2006.

[10] M. M. Al-Barbasy, Politik Perda Syariat: Dialektika Islam dan Pancasila di Indonesia. Yogyakarta: Suara Muhammadiyah, 2018.

[11] M. M. Al-Barbasy, "Islam dan Negara: Perdebatan dalam Pembuatan Perda Syariat di Kota Tasikmalaya," Afkaruna Indones. Interdiscip. J. Islam. Stud., vol. 12, no. 2, 2016.

[12] R. Bush, "10 Regional Sharia Regulations in Indonesia: Anomaly or Symptom?," Expressing Islam Relig. life Polit. Indones., p. 174, 2008.

[13] A. Salim, Challenging the secular state: The Islamization of law in modern Indonesia. University of Hawaii Press, 2008.

[14] M. Duverger and L. Hasyim, Partai politik dan kelompok-kelompok penekan. PT. Bina Aksara, Jakarta, 1984. 